Acta Theriologica 42 (3): 241-252, 1997.

PL ISSN 0001-7051

\title{
Wolf number changes in Bieszczady National Park, Poland
}

\author{
Wojciech ŚMIETANA* and Jacek WAJDA
}

\begin{abstract}
Śmietana W. and Wajda J. 1997. Wolf number changes in Bieszczady National Park, Poland. Acta Theriologica 42: 241-252.

From 1991 to 1995, wolf Canis lupus (Linnaeus, 1758) population dynamics were studied in Bieszczady National Park and the surrounding area $\left(520 \mathrm{~km}^{2}\right)$. The study area was utilized by 5 packs. Pack sizes averaged 5.6 in early and 3.9 in late winter. Overwinter declines in wolf numbers ranged from $21 \%$ to $39 \%(\bar{x}=29 \%)$, which corresponded well to the known number of wolves killed by hunters or dead of other causes. After every winter decline, wolf numbers recovered through reproduction. Generally, wolf numbers were stable or slightly decreasing during the study. Three neighbouring wolf packs occupied an area of $340 \mathrm{~km}^{2}$ and the estimated territory size averaged $85 \mathrm{~km}^{2}$. The estimated density of wolves averaged $5.1 / 100 \mathrm{~km}^{2}$ in early winter and $3.3 / 100 \mathrm{~km}^{2}$ in late winter. Of all known causes of wolf mortality, $86 \%$ were from legal hunting, $5 \%$ were from poaching, and $9 \%$ were from natural causes. Bieszczady National Park is small in size and its topography influences the spatial distribution of packs. No single pack was fully contained within, or protected by the Park. The number of wolves is overestimated in official reports, because the same packs are likely counted as different groups in neighbouring census units. On hunting grounds adjacent to Bieszczady NP, harvest plans exceed the actual number of wolves which inhabit the area. The creation of a wolf protection zone around Bieszczady NP and some regulations for wolf management in the rest of the region are proposed.

Institute of Nature Conservation, Polish Academy of Sciences, Lubicz 46, 31-512 Cracow, Poland (WŚ); Bieszczady National Park, Research and Education Centre, 38-700 Ustrzyki Dolne, Poland (JW)

Key words: wolf, population dynamics, conservation, management, Carpathians, Poland
\end{abstract}

\section{Introduction}

Nowadays, wolves Canis lupus (Linnaeus, 1758) inhabit mainly the Carpathians and the central-east and north-eastern parts of Poland, with a small population living in the western part of the country (Okarma 1993). Officially, about 850 wolves are estimated in the country at present (GUS 1994). The highest wolf density is recorded in the Carpathians. Of all wolves killed in the country from 1980 to 1990, about 40\% (559 individuals) were harvested in Krosno Province situated in the east part of the Polish Carpathians (Okarma 1992).

*Mailing address: Zatwarnica-Suche Rzeki, 38-715 Dwernik, Poland 
In Poland, wolves were recognised as a game species in 1975. Since then, only hunters have been allowed to kill them. The only permitted form of hunting has been shooting with rifles, and the number of animals to be killed has been limited. A protected period was established between 1 April and 31 July for all Poland except areas of high wolf density (Carpathians), where hunting was allowed throughout the year. Between 1981 and 1995, seasonal protection was extended to all of the country. Since 1995, wolves received status of protected species with exception of 3 provinces (Krosno, Przemyśl and Suwałki) were they can be hunted during a 4 month hunting season between 1 November and the end of February.

Since 1973 in Krosno province, wolves have been protected only in Bieszczady National Park. One of the goals of the Park is conservation of forest fauna. Because the Park is surrounded by intensively used hunting grounds, the question of its effectiveness in wolf protection occurs.

We investigated population changes, mortality and territory size of wolves which utilized Bieszczady National Park. From this research, we will evaluate the role of the Park for protection of wolves and propose some regulations for wolf management in the region.

\section{Study area}

The study was conducted in the Bieszczady Mountains (a range within the Carpathians) within Bieszczady National Park (BNP) $\left(271 \mathrm{~km}^{2}\right)$ and adjacent parts of hunting districts. The total study area was $520 \mathrm{~km}^{2}$. The area is part of the International Biosphere Reserve "East Carpathians" $\left(1538 \mathrm{~km}^{2}\right)$ set up in 1993 in the territories of Poland, Slovakia and Ukraine. The total area of the Polish portion of the Reserve amounts to $1090 \mathrm{~km}^{2}$ (Fig. 1).

Long parallel ridges are typical of the Bieszczady Mountains landscape. BNP covers higher parts of the Bieszczady Mountains, with the highest peak, Tarnica, at $1346 \mathrm{~m}$ a.s.l.. The lowest elevations in the study area lie at $450 \mathrm{~m}$ a.s.l. outside BNP. About $80 \%$ of the study area is covered by forest. Beech Fagus silvatica dominate, and fir Abies alba, spruce Picea excelsa, grey alder Alnus incana, and sycamore Acer pseudoplatanus are important (Zarzycki 1963). Areas above $1150 \mathrm{~m}$ a.s.l. are covered by subalpine meadows, called in Polish "połonina", with Vaccinium myrtillus and a variety of grasses (Zarzycki and Głowaciński 1986). The average annual air temperature is $4.9^{\circ} \mathrm{C}$. Annual precipitation is $800-1200 \mathrm{~mm}$. Snow cover persists for 4-5 months and its thickness may exceed $1.5 \mathrm{~m}$ (Michna and Paczos 1972). The area is relatively sparsely populated by humans $\left(5 / \mathrm{km}^{2}\right)$. The main economy outside BNP is forestry. There is limited grazing of sheep, cattle, goats and horses, and very little agriculture.

During the 1991-1995 period, red deer Cervus elaphus were the most numerous wild ungulates in the area (midwinter density -4.0 ind. $/ \mathrm{km}^{2}$ ), followed by roe deer Capreolus capreolus $-1.0 / \mathrm{km}^{2}$ and wild boar Sus scrofa $-0.3 / \mathrm{km}^{2}$. European bison Bison bonasus and moose Alces alces were scarce -0.06 and $0.008 / \mathrm{km}^{2}$, respectively (Śmietana and Wajda, unpublished report 1995).

The bison was reintroduced here in the $1960 \mathrm{~s}$ and is a protected species, but its numbers have been regulated outside the Park by hunting. Moose, which immigrated here in the $1980 \mathrm{~s}$, are not hunted. The other three species are exploited within the hunting grounds. Inside the Park, only the red deer number is controlled by yearly reductions. Apart from wolves, there are other large predators, such as lynx Lynx lynx and brown bear Ursus arctos, both protected species. In the area, wolves feed mostly on red deer, and are independent of anthropogenic sources of food (Śmietana and Klimek 1993). 


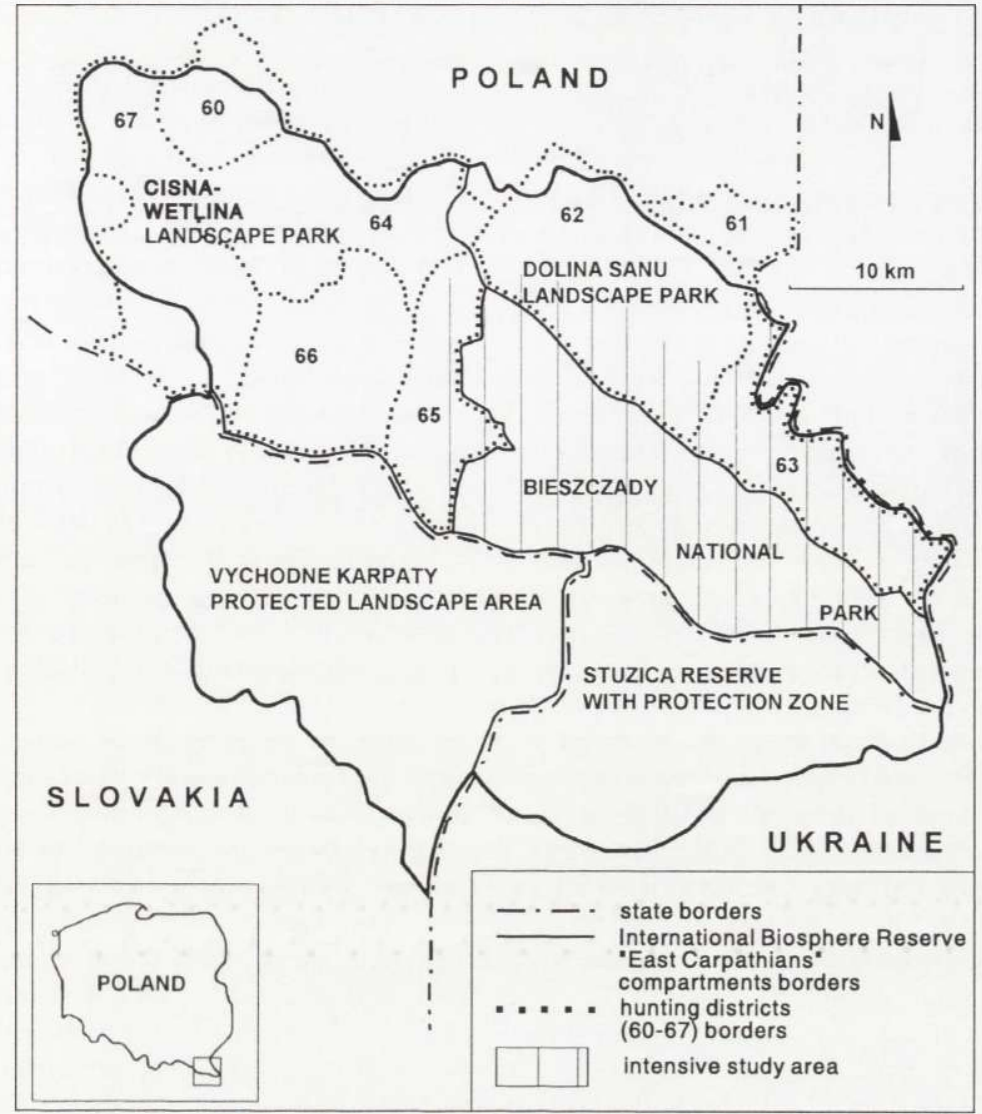

Fig. 1. Location of the study area, in relation to the borders of Bieszczady National Park, adjacent hunting districts and the International Biosphere Reserve "East Carpathians".

\section{Methods}

Wolf populations are most frequently studied using radiotelemetry (eg Mech and Frenzel 1971, Fritts and Mech 1981, Ballard et al. 1987, Fuller 1989). Aerial snow tracking has also been used (eg Mech 1966, Gaseway et al. 1983). Some studies have combined aerial snow tracking with radio-tracking (eg Hayes et al. 1991). Because we lacked permission for livetrapping wolves and also due to dense forest cover, only ground snow tracking was available to us.

We believe that the number and spatial distribution of packs which utilized relatively small area can be deduced from the spatial-temporal distribution of wolf tracks recorded during frequent surveys of the area because: (1) wolves are social animals, living mainly in packs (Mech 1988a, b), whose members usually travel, rest and hunt together during winter (Mech 1966, Fuller 1991); (2) wolf packs occupy exclusive territories (eg Fritts and Mech 1981, Ballard et al. 1987, Potvin 1988, Fuller 1989), often with relatively stable from year to year boundaries (Mech 1975, Mech 1977a, Fuller 
1989); (3) alien wolves are not tolerated by resident packs (Peters and Mech 1975, Messier 1985, Mech 1993).

Data were collected within BNP by $6-8$ park rangers and by the authors throughout the study area on a grid of forest paths of total length about $150 \mathrm{~km}$, surveyed from one to dozen times every month. Wolf tracks in snow were recorded from early November until early April during four consecutive winter seasons, 1991-1995. Every record contained the number of wolves read from tracks in snow or observed, approximate or exact date of wolf passing, location or a schematic map of travel route made by wolves. Records were plotted on 1: 25000 topography maps and travel routes of wolves were measured. After every winter season collected data were analyzed to determine the number and approximate spatial distribution of the packs which, at least partially, utilized the BNP.

Preliminarily, we assumed that fresh tracks could have been left by separate groups if on the same day they were found at least $8 \mathrm{~km}$ apart. We chose this distance because smallest known wolf pack territories covered $50 \mathrm{~km}^{2}$ (Fuller 1989), and centres between theoretical adjacent $50 \mathrm{~km}^{2}$ territories of circular shape lie $8.0 \mathrm{~km}$ apart. In this way, we determined location of ranges (territory fragments) utilized by presumably separate packs. Wolf group which crossed the determined territory fragment was believed to be the same pack every time (exclusiveness of territories), unless we knew or suspected that passing wolves belonged to another wolf pack, eg when presence of two groups in one place was recorded ( 2 cases); when a singular presence of a very large group within an area utilized by a small group was recorded ( 1 case); or long distance tracking indicated a wolf pack excursion into the territory of a neighbouring pack ( 3 cases).

We estimated spatial distribution of wolf pack territories by studying travel routes of individual packs. Because some fragments of routes were frequently used by packs every winter we believe, that the same packs used the same ranges during the study. Therefore their territory boundaries were estimated on the basis of all collected records. Although we were not permitted to cross the state border our data and interviews with local foresters and the state border patrols suggest that wolves do not cross the fence stretched on the Ukrainian side of the border. Thus, we assumed that based on our records delineation of territory boundaries of packs, which utilized the area along Polish-Ukrainian border, did not result in significant underestimation of size of their territories. Territory size was estimated by measuring with a planimeter an area delineated by connecting the outermost tracks left by a given wolf pack. In case of Ustrzyki pack we excluded an area overlapping with Dwernik pack territory where Ustrzyki pack was never recorded.

During the winter 1994/1995, Dwernik wolf pack was tracked intensively to define the size of its territory more accurately. To verify if the determined territory is utilised only by one wolf pack, three times, $6-18 \mathrm{~h}$ after fresh snowfall, the area (except small area to the west from Wołosaty stream which overlapped with territory of Ustrzyki pack; see Fig. 3) was surveyed simultaneously by five persons on a grid of forest paths of total length $45 \mathrm{~km}$.

Pack size in early (November-December) or late (March-April) winter was the maximum number of wolves recorded in the given pack. In 1992/93 winter season in Wetlina pack more wolves were recorded in late winter ( 10 wolves observed) than in early winter ( 9 wolves estimated from tracks). In this case we used late winter observation also for early winter estimate of the pack size.

Proportion of lone wolves in the population was estimated from the ratio of single wolves to pack wolves recorded. The number of lone wolves are considered as maxima, because we could not distinguish a true lone wolf from a pack member that was temporarily travelling on its own.

Calculations of wolf population changes were based only on the number of wolves in packs. The number of lone wolves was not included because their proportion in the population was low and relatively stable $(2-5 \%)$. Annual rates of increase in wolf numbers were expressed by the ratio of successive yearly estimates in late winter.

Wolf density was estimated by delineating the census area that encompassed determined territories of neighbouring packs and the area between them. The summed pack sizes plus the estimated proportion of lone wolves were divided by the census area to calculate winter densities. The mean litter size was estimated from counts of embryos in reproductive tracts of killed females and 
from field records of pups observed in June. Mortality factors were determined from official reports on the number of wolves killed within hunting districts adjacent to BNP, and from carcasses of dead wolves found by the authors and personnel of BNP and State Forest. The number of wolves dead from causes other than legal hunting are considered as minimal numbers because presumably not every carcass was found.

\section{Results}

\section{Distribution of wolf packs and territory size}

We collected $71,133,167$, and 97 records, representing 17.9, 69.8, 146.3, and $139.7 \mathrm{~km}$ of snow tracking during consecutive four winter seasons. Every winter the study area was utilized by 5 wolf packs with apparently stable territories. Long ridges of "połonina" covered by deep snow constituted borders between packs at least during winters (Fig. 2).

We estimated the boundaries of three wolf packs inhabiting the eastern part of the study area, encompassing $340 \mathrm{~km}^{2}$ (Fig. 2). The borders of the remaining two packs were defined only partially as these packs used areas also out of the study area. Dwernik, Ustrzyki and Bukowiec wolf packs territories were determined on the basis of $87,90,59$ records, representing $131.6,67.2,25.0 \mathrm{~km}$ of tracking. The territory size averaged $85 \mathrm{~km}^{2} ; 84,90,82 \mathrm{~km}^{2}$ for Dwernik, Ustrzyki and Bukowiec packs, respectively. The overlap between the territories amounted

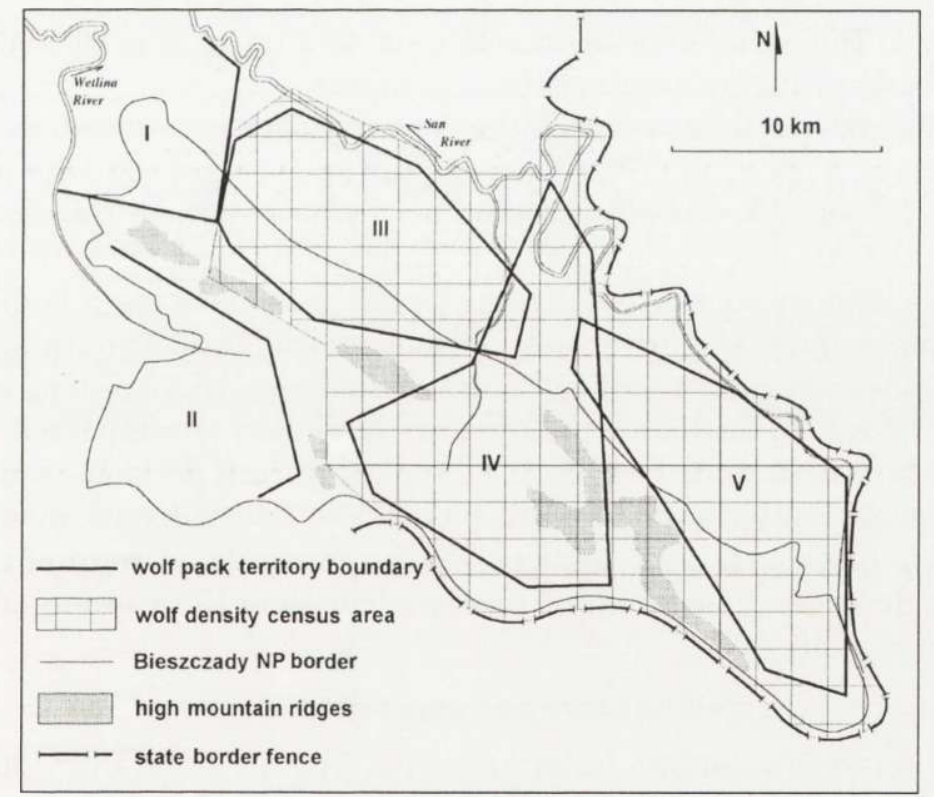

Fig. 2. Distribution of wolf packs studied in the Bieszczady Mountains in 1991-1995. Pack names: I - Hulskie, II - Wetlina, III - Dwernik, IV - Ustrzyki, V - Bukowiec. 


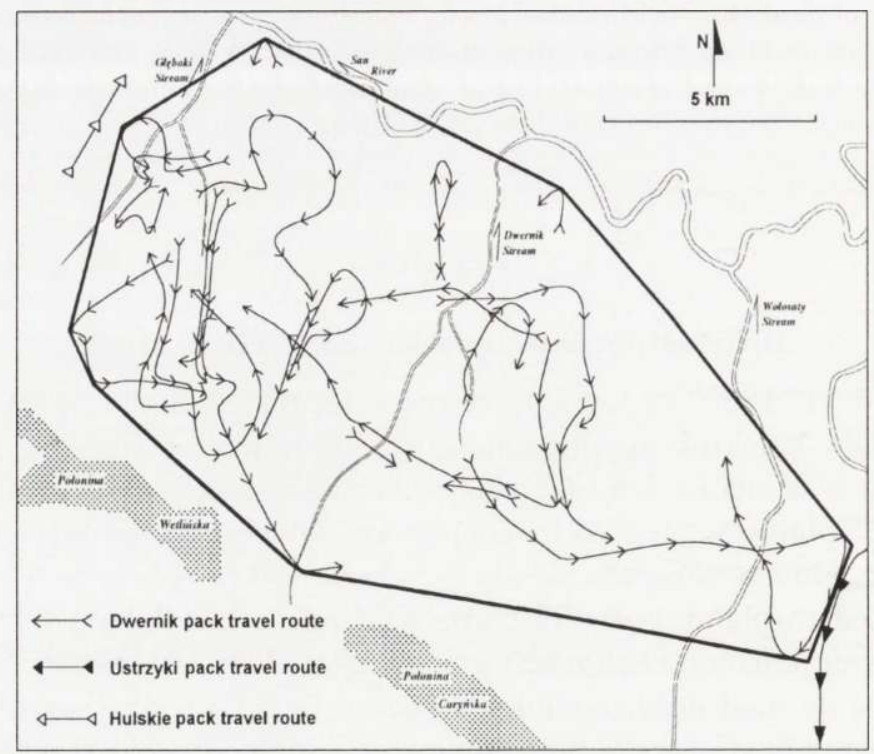

Fig. 3. Dwernik pack travel routes followed during winter season 1994/95 in the Bieszczady Mountains and determined territory boundary of the pack.

to $7 \mathrm{~km}^{2}(3 \%)$. The area between the adjacent territories was $91 \mathrm{~km}^{2}(27 \%)$, and consisted mostly of higher parts of the mountains.

During the 1994/95 winter season the Dwernik pack of 4-2 wolves was tracked over a distance of $88.3 \mathrm{~km}$. The longest continuous tracking was made over a distance of $17.3 \mathrm{~km}$. The pack utilized an area whose natural borders constituted Połonina Wetlińska and Połonina Caryńska, and the San River (Fig. 3). During one snow tracking we found that Dwernik pack was following a trail of Ustrzyki pack. We found a number of urine markings along this trail. The trail fixed eastern boundary of Dwernik pack territory. The territory was $15.5 \mathrm{~km}$ long and 8.2 wide and covered $84 \mathrm{~km}^{2}$. The delineated territory boundary encompassed every travel routes that were determined as left by the pack during previous winter seasons. During three consecutive surveys of the territory of Dwernik pack made after fresh snowfalls simultaneously by 5 persons we recorded: (1) a group of three wolves plus one single wolf, (2) a group of three wolves, and (3) a group of two wolves plus one single wolf.

\section{Wolf numbers and population density}

The total number of wolves in packs varied from 23 to 33 individuals in early winter, and 16 to 23 in late winter. The mean number of wolves per pack ranged from 4.6 to $6.6(\bar{x}=5.6)$ in early winter versus 3.2 to $4.6(\bar{x}=3.9)$ in late winter. Maximum pack size was 10 individuals (Table 1). 
Table 1. E - early (November-December) and L - late (March-April) winter estimates of individual wolf pack size in the Bieszczady Mountains study area in winter seasons 1991-1995.

\begin{tabular}{|c|c|c|c|c|c|c|c|c|c|c|c|c|}
\hline \multirow{3}{*}{ Winter } & \multicolumn{10}{|c|}{ Wolf pack name } & \multirow{2}{*}{\multicolumn{2}{|c|}{ Average }} \\
\hline & \multicolumn{2}{|c|}{ Hulskie } & \multicolumn{2}{|c|}{ Wetlina } & \multicolumn{2}{|c|}{ Dwernik } & \multicolumn{2}{|c|}{ Ustrzyki } & \multicolumn{2}{|c|}{ Bukowiec } & & \\
\hline & $\mathrm{E}$ & $\mathrm{L}$ & $\mathrm{E}$ & $\mathrm{L}$ & $\mathrm{E}$ & $\mathrm{L}$ & $\mathrm{E}$ & $\mathrm{L}$ & E & $\mathrm{L}$ & $\mathrm{E}$ & $\mathrm{L}$ \\
\hline $1991 / 92$ & 4 & 4 & 5 & 5 & 6 & 3 & 5 & 3 & 6 & 4 & 5.2 & 3.8 \\
\hline $1992 / 93$ & 5 & 2 & 10 & 10 & 3 & 3 & 3 & 2 & 8 & 6 & 5.8 & 4.6 \\
\hline $1993 / 94$ & 6 & 3 & 7 & 6 & 9 & 5 & 4 & 2 & 7 & 4 & 6.6 & 4.0 \\
\hline $1994 / 95$ & 3 & 2 & 5 & 3 & 4 & 3 & 4 & 3 & 7 & 5 & 4.6 & 3.2 \\
\hline Mean & 4.5 & 2.8 & 6.8 & 6.0 & 5.5 & 3.5 & 4.0 & 2.5 & 7.0 & 4.8 & 5.6 & 3.9 \\
\hline
\end{tabular}

Overwinter declines in mean pack size ranged from $21 \%$ to $39 \%(\bar{x}=29 \%)$ and corresponded well to the number of wolves killed within hunting districts adjacent to BNP and the number of wolves otherwise found dead in the area (Table 2). Each year from late winter to the beginning of the next winter season, wolf numbers increased between $15 \%$ and $53 \%(\bar{x}=37 \%)$. Wolf numbers recovered fully after overwinter declines of $21 \%$ and $27 \%$, but did not recover fully after a $39 \%$ winter population loss. Annual rates of increase of the wolf number ranged from 0.80 to $1.21(\bar{x}=0.96)$ (Table 2$)$.

Apart from the five packs we also recorded tracks of single wolves. We calculated the number of loners at 2, 3, 5 and $4 \%$ of the total wolf number during consecutive years of the study. Thus, the study area was utilized by 1-2 lone wolves every year. The estimated density of wolves varied from 6.2 to $4.3 / 100 \mathrm{~km}^{2}$ $(\bar{x}=5.1)$ in early winter and $3.4-3.1 / 100 \mathrm{~km}^{2}(\bar{x}=3.3)$ in late winter (Table 3).

Table 2. Wolf population changes and numbers of wolves killed or otherwise found dead in the Bieszczady Mountains study area in winter seasons 1991-1995. E - November-December, L March-April estimates. ${ }^{a}$ Only wolves from packs are included. ${ }^{b}$ Within BNP and hunting districts: $62,63,65$ (see Fig. 1), totally $720 \mathrm{~km}^{2}$.

\begin{tabular}{lcccccc}
\hline Winter & Wolf numbers & a & $\begin{array}{c}\text { Overwinter } \\
\text { decline of } \\
\text { wolf number }\end{array}$ & $\begin{array}{c}\text { Numbers of } \\
\text { wolves found } \\
\text { dead plus } \\
\text { hunted }\end{array}$ & $\begin{array}{c}\text { Summer } \\
\text { increase } \\
\text { of wolf } \\
\text { number }\end{array}$ & $\begin{array}{c}\text { Annual } \\
\text { rate of } \\
\text { increase }\end{array}$ \\
\hline $1991 / 92$ & 26 & 19 & $-7(27 \%)$ & $0+9$ & $10(53 \%)$ & - \\
$1992 / 93$ & 29 & 23 & $-6(21 \%)$ & $4+6$ & $10(43 \%)$ & 1.21 \\
$1993 / 94$ & 33 & 20 & $-13(39 \%)$ & $1+13$ & $3(15 \%)$ & 0.87 \\
$1994 / 95$ & 23 & 16 & $-7(30 \%)$ & $1+9$ & - & 0.80 \\
Mean & 27.8 & 19.5 & $-8.2(29 \%)$ & $1.5+9.2$ & $7.7(37 \%)$ & 0.96 \\
\hline
\end{tabular}


Table 3. Wolf density estimates in the Bieszczady Mountains study area during winter seasons 1991-1995.

\begin{tabular}{lcc}
\hline \multirow{2}{*}{ Winters } & \multicolumn{2}{c}{ Estimated density (wolves $/ 100 \mathrm{~km}^{2}$ ) } \\
\cline { 2 - 3 } & November-December & March-April \\
\hline $1991 / 92$ & 5.3 & 3.1 \\
$1992 / 93$ & 4.3 & 3.4 \\
$1993 / 94$ & 6.2 & 3.4 \\
$1994 / 95$ & 4.6 & 3.4 \\
Mean & 5.1 & 3.3 \\
\hline
\end{tabular}

Reproduction and mortality

The litter size of one female whose reproductive tracts were examined ( 8 embryos found) and of another two whose pups were seen in June (5 and 6 pups) averaged 6.3. We collected information about mortality causes for 43 dead wolves in the study area. Of this number, $86 \%$ were legally killed by hunters, $5 \%$ were poached ( 1 shot, 1 snared), and 9\% died because of natural reasons (1 killed by another wolf, and 3 died probably due to disease or malnutrition). Of the 9 dead wolves examined, 5 were adult males, 2 were adult females and 2 were female pups.

\section{Discussion}

Wolf pack territory size is correlated to variation in prey density (Fuller 1995). The relatively small territory sizes found in the study area $\left(\bar{x}=85 \mathrm{~km}^{2}\right)$ is probably related to the high density of prey, especially red deer $\left(4.0 / \mathrm{km}^{2}\right)$, and the high density of wolves.

The average density of wolves $\left(4.2 / 100 \mathrm{~km}^{2}\right)$ in the Bieszczady Mountains is one of the highest found anywhere (for comparison see Fuller 1989). Studies conducted in North America indicate that the variation of wolf density is explained by the variation in ungulate biomass, and the potential wolf density could be calculated from the regression equation (Fuller 1989 modified by Messier 1995): $y=0.419 x$, where $y$ - wolves $/ 100 \mathrm{~km}^{2}, x$ - ungulate biomass index $/ \mathrm{km}^{2}, r^{2}=0.92$, $\mathrm{df}=24, p<0.001$. The ungulate biomass index is based on Odocoileus units (Keith 1983 after Fuller 1989). On the basis of the average body mass of subadults and adults, European bison (Krasińska 1988), moose (Dzięciołowski and Pielowski 1993), red deer (Bobek et al. 1992), wild boar (Fruziński 1992), and roe deer (Pielowski 1988), we assigned relative biomass index values of: 8 for European bison, 5 for moose, 2.5 for red deer, 1.5 for wild boar, and 0.5 for roe deer. Thus, the ungulate biomass index calculated for the Bieszczady Mountains (see "Study 
area" for ungulate densities) equals $11.6 / \mathrm{km}^{2}$. According to the regression equation, wolf density should stabilize at $4.9 / 100 \mathrm{~km}^{2}$, which is close to our estimates.

Fuller (1989) analyzed changes in wolf populations in North America and concluded that an average total annual mortality above $35 \%$ (not including mortality of pups less than 6 months of age) leads to wolf population declines. In our study, wolf numbers recovered after $21 \%$ and $27 \%$ overwinter declines, but did not recover fully after a $39 \%$ decline, which seems to agree with his conclusions. However, it must be noted that overwinter losses could result from both mortality and dispersal. Because overwinter declines every year corresponded well to the number of wolves killed by hunters and other causes in the area we think that mortality rather than dispersion was the main cause of overwinter declines. Because overwinter declines of wolf numbers $(\bar{x}=29 \%)$ were close to the critical value of population stability $(35 \%)$ it is likely that population of wolves produced no or very few dispersals. It must be noted also that overwinter declines represent only autumn-winter mortality rate. Thus, annual mortality rate was probably somewhat higher.

After every winter decline, wolf numbers increased. We believe that reproduction was the main cause of increase (with no or very little immigration) because hunting of wolves in our study area did not seem to completely eliminate packs.

We found that lone wolves composed $2-5 \%$ of the local population, which is rather low proportion. Studies conducted in North America note that lone wolves usually composed 2-29\% of a winter population (Fuller and Keith 1980, Messier 1985, Ballard et al. 1987, Fuller 1989).

In North America, the average litter size usually varies between 4 and 8 (eg Mech 1977b, Gasaway et al. 1983, Fuller 1989, Hayes et al. 1991) and the variation is correlated with prey biomass available per wolf (Fuller 1995). Data on wolf litter size indicate similar reproduction potential in Eurasia (Bibikov 1985, Blanco et al. 1990, Jędrzejewska et al. 1996). In our study, data were limited but fit well within the above range.

\section{Management implications}

Assuming that the wolf density throughout the Bieszczady Mountains (BNP and hunting districts: $60-67$, totally $1253 \mathrm{~km}^{2}$; see Fig. 1) does not differ from that calculated for our study area, we estimate the total number of wolves in this mountain range to be $54-77(\bar{x}=64)$ in early winter and $39-43(\bar{x}=41)$ in late winter. The estimated average overwinter decline of 23 (15-34) individuals corresponds well to the average of 16.5 (14-22) wolves killed annually (from 1991 to 1995$)$ by hunters plus the suspected minimum of $3(2-5)$ wolves (14\% of total number of dead wolves) dead because of other reasons. For the same area (1253 $\mathrm{km}^{2}$ ), the official data of the State Forest and BNP administration reported for 1991-1995 the presence of 99-123 wolves at the end of winter (31 March), 2.5-3 
times more than our estimates. In the Bieszczady Mountains the officially recorded density of ungulates, averaged 1.8 red deer, 0.9 roe deer, 0.3 wild boar, 0.08 European bison, and 0.008 moose per $1 \mathrm{~km}^{2}$. Ungulate biomass index calculated on this basis equals 6.2, and according to the regression equation (Fuller 1989 modified by Messier 1995) wolf density should stabilize at about $2.6 / 100 \mathrm{~km}^{2}$, which contrasts with the officially recorded density of 9.2 wolves $/ 100 \mathrm{~km}^{2}$. The results of our study indicate that the official number of wolves is an overestimate. Trokowicz (1980) tracking wolves in Biebrza River Valley (north-eastern Poland) concluded the same.

In our opinion, the overestimation of wolf density in official reports is mainly the result of the census method. According to the official instructions, wolf numbers are determined within all hunting districts or National Park by snow tracking and year-round observations. Because both hunting districts (usually $30-200 \mathrm{~km}^{2}$ ) and National Parks (BNP is only $271 \mathrm{~km}^{2}$ ) are relatively small and constitute only portions of forest complexes, the same packs are likely counted as different groups in neighbouring census units.

Assuming an $80 \%$ summer increase of wolf numbers, the game managers planned to harvest 66-84 wolves annually (during winters 1991-1995) in the Bieszczady Mountains. Our study indicates that a successful hunt of this magnitude would cause a complete destruction of the population.

\section{Conclusions}

(1) Bieszczady National Park is small in size and its topography influences the spatial distribution of packs. No single pack is fully contained within, or protected by the Park. Thus, we propose to establish a wolf protection zone around BNP, which would include, at least, the adjacent hunting districts $(62,63,65$; Fig. 2).

(2) Since the official number of wolves is overestimated and the number of wolves planned to be killed exceeds the number of wolves living in the area, we suggest reducing the harvest quota to maximum $30 \%$ of the early winter population number. [The maximum harvest quota of wolves was obtained by multiplying maximum average mortality not leading to population decline $(35 \%)$ by contribution of hunting caused mortality to the total mortality (0.86)]. At present, the planned harvest quota in the Bieszczady Mountains should not exceed 19 wolves.

Acknowledgments: We gratefully acknowledge: W. Wiśniewski, B. Kochanowicz, W. Kalinowski, P. Szpiech, A. Derwich, T. Kwolek, E. Kopczak, W. Pietrasz, B. Kopczak (BNP rangers) who assisted in the field work. W. Wojciechowski (director of BNP), T. Winnicki, W. Holly who provided logistical help, L. Bekier who kindly let us stay at his house during the first two years of the project and C. Kalley who improved the English text. Biology students of the Neuchâtel University (Switzerland) volunteered in snow tracking in winter 1994/95. We are indebted to Dr F. K. Harrington for comments and linguistic correction. The study was partially financed by BNP from resources of The National Fund for Environmental Protection. 


\section{References}

Ballard W. B., Whitman J. S. and Gardner G. L. 1987. Ecology of an exploited wolf population in south-central Alaska. Wildllife Monographs 98: 1-54.

Bibikov D. I. (ed) 1985. [The wolf]. Izdatelstvo Nauka, Moskva: 1-606. [In Russian]

Blanco J. C., Cuesta L. and Reig S. (eds) 1990. [The wolf (Canis lupus) in Spain]. ICONA, Madrid: 1-118. [In Spanish with English summaries]

Bobek B., Morow K., Perzanowski K. and Kosobucka M. 1992. [The red deer (Cervus elaphus) - its ecology and management.] Wydawnictwo Świat, Warszawa: 1-200. [In Polish]

Dzięciołowski R. and Pielowski Z. 1993. [The elk]. Wydawnictwo Anton-5, Warszawa: 1-208. [In Polish]

Fritts S. H. and Mech L. D. 1981. Dynamics, movements, and feeding ecology of a newly protected wolf population in northwestern Minnesota. Wildlife Monographs 80: 1-79.

Fruziński B. 1992. [The wild boar]. Wydawnictwo Cedrus, Warszawa: 1-248. [In Polish]

Fuller T. K. 1989. Population dynamics of wolves in north-central Minnesota. Wildlife Monographs 105: 1-41.

Fuller T. K. 1991. Effects of snow depth on wolf activity and prey selection in north central Minnesota. Canadian Journal of Zoology 69: 283-287.

Fuller T. K. 1995. Guidelines for gray wolf management in the northern Great Lakes Region. Technical Publication 271. International Wolf Center, Ely: 1-19.

Fuller T. K. and Keith L. B. 1980. Wolf population dynamics and prey relationships in northeastern Alberta. Journal of Wildlife Management 44: 583-602.

Gasaway W. C, Stephenson R. O., Davis J. L., Shepherd P. E. K. and Burris O. E. 1983. Interrelationships of wolves, prey, and man in interior Alaska. Wildlife Monographs 84: 1-50.

GUS. 1994. [Environmental protection 1994]. GUS, Warszawa: 1-518. [In Polish]

Hayes R. D., Baer A. M. and Larsen D. G. 1991. Population dynamics and prey relationships of an exploited and recovering wolf population in southern Yukon. Yukon Fish and Wildlife Branch Final Report TR-91-1: 1-67.

Jędrzejewska B., Jędrzejewski W., Bunevich A. N., Miłkowski L. and Okarma H. 1996. Population dynamics of wolves Canis lupus in Białowieża Forest (Poland and Belarus) in relation to hunting by humans, 1847-1993. Mammal Review 26: 103-126.

Krasińska M. 1988. [Hybrids of European bison and domestic cattle]. Ossolineum, Wrocław: 1-188. [In Polish]

Mech L. D. 1966. The wolves of Isle Royale. Fauna of the National Parks of the United States, Fauna Series 7: 1-210.

Mech L. D. 1975. Population trend and winter deer consumption in a Minnesota wolf pack. Proceedings of the 1975 Predator Symposium: 55-83.

Mech L. D. 1977a. Wolf-pack buffer zones as prey reservois. Science 198: 320-321.

Mech L. D. 1977b. Productivity, mortality, and population trends of wolves in northeastern Minnesota. Journal of Mammalogy 58: 559-574.

Mech L. D. 1988a. The wolf. The ecology and behavior of an endangered species. University of Minnesota Press, Minneapolis: 1-384.

Mech L. D. 1988b. The Arctic wolf. Living with the pack. Voyageur Press, Stillwater: 1-128.

Mech L. D. 1993. Details of a confrontation between two wild wolves. Canadian Journal of Zoology 71: 1900-1903.

Mech L. D. and Frenzel L. D. (eds) 1971. Ecological studies of the timber wolf in northeastern Minnesota. USDA Forest Service Research Paper NC-52: 1-67.

Messier F. 1985. Social organization, spatial distribution, and population density of wolves in relation to moose density. Canadian Journal of Zoology 63: 1068-1077. 
Messier F. 1995. On the functional and numerical responses of wolves to changing prey density. [In: Ecology and conservation of wolves in a changing world. L. N. Carbyn, S. H. Fritts and D. R. Seip, eds]. Canadian Circumpolar Institute, Edmonton, Alberta: 185-197.

Michna E. and Paczos S. 1972. [Climate of the Bieszczady Mountains]. Ossolineum, Wrocław: 1-72. [In Polish]

Okarma H. 1992. [The wolf]. Privartely published, Białowieża: 1-168. [In Polish]

Okarma H. 1993. Status and management of the wolf in Poland. Biological Conservation 66: 153-158.

Peters R. P. and Mech L. D. 1975. Scent-marking in wolves. American Scientist: 63: 628-637.

Pielowski Z. 1988. [The roe deer]. Państwowe Wydawnictwo Rolnicze i Leśne, Warszawa: 1-292. [In Polish]

Potvin F. 1988. Wolf movements and population dynamics in Papineau-Labelle Reserve, Quebec Canadian Journal of Zoology 66: 1266-1273.

Pucek Z. (ed) 1984. [Key for identification of Polish mammals]. Polish Scientific Publishers, Warszawa: 1-383. [In Polish]

Śmietana W. and Klimek A. 1993. Wolf diet in the Bieszczady Mountains, Poland. Acta Theriologica 38: $245-251$.

Trokowicz L. 1980. [Tracking wolves in Biebrza River Valley]. Przegląd Zoologiczny 24: 137-145. [In Polish]

Zarzycki K. 1963. [Forests of the Bieszczady Mountains]. Acta Agraria et Silvestria II: 19-24. [In Polish]

Zarzycki K. and Głowaciński Z. 1986. [The Bieszczady Mountains]. Wiedza Powszechna, Warszawa: 1-180. [In Polish]

Received 6 November 1996, accepted 11 June 1997. 